\title{
The Middle Eastern and biblical origins of the Mediterranean diet
}

\author{
Elliot $M$ Berry $^{1, *}$, Yardena Arnoni ${ }^{1}$ and Michael Aviram ${ }^{2}$ \\ 'Department of Human Nutrition and Metabolism, Braun School of Public Health, Hebrew University-Hadassah \\ Medical School, PO Box 12272, Jerusalem, 91120, Israel: ${ }^{2}$ The Lipid Research Laboratory, Technion Rappaport \\ Faculty of Medicine, and the Legacy - Heritage Clinical Research Institute at Rambam (LHCRIR) Maimonides \\ Medical Center, Haifa, Israel
}

Submitted 13 May 2011: Accepted 7 September 2011

\begin{abstract}
Objective: To place the Mediterranean diet (MedDi) in the context of the cultural history of the Middle East and emphasise the health effects of some of the biblical seven species - wheat, barley, grapes, figs, pomegranates, olives and date honey. Design: Review of the literature concerning the benefits of these foods.

Setting: Middle East and Mediterranean Basin.

Subjects: Mediterranean populations and clinical studies utilising the MedDi.

Results and conclusions: The MedDi has been associated with lower rates of CVD, and epidemiological evidence promotes the benefits of consuming fruit and vegetables. Recommended foods for optimal health include whole grain, fish, wine, pomegranates, figs, walnuts and extra virgin olive oil. The biblical traditional diet, including the seven species and additional Mediterranean fruits, has great health advantages, especially for CVD. In addition to the diet, lifestyle adaptation that involves increasing physical activity and organised meals, together with healthy food choices, is consistent with the traditional MedDi. The MedDi is a manageable, lifestyle-friendly diet that, when fortified with its biblical antecedent attributes, may prove to be even more enjoyable and considerably healthier in combating the obesogenic environment and in decreasing the risks of the non-communicable diseases of modern life than conventional, modern dietary recommendations. The biblical seven species, together with other indigenous foods from the Middle East, are now scientifically recognised as healthy foods, and further improve the many beneficial effects of the MedDi.
\end{abstract}

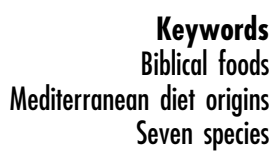

The Mediterranean diet (MedDi) is considered today to be among the healthiest of diets, with evidence of increased longevity and protection against CVD and cancer. The geographic and evolutionary origins of the diet are of interest as they encompass the history of Western civilisation. The rise of agriculture (domestication of crops) and animal husbandry took place from 10000 to 4000 BCE, while the wheel, metallurgy, writing and city states arose from 4000 to 1000 BCE. These essential developments in the evolution of civilisation originated in the fertile crescent from Mesopotamia, the ancient near East, Canaan and Egypt. The biblical period from the time of the Patriarchs until King David in Jerusalem was from 1750 to 1100 BCE with the fall of Troy and the Greek colonisation of Ionia occurring in the twelfth century BCE.

Evidence of dietary patterns has been obtained from archaeo-botany and written records. Although there are many similarities between the traditional Greek (Cretan) MedDi and that described in the Pentateuch, the differences are of interest as they have special nutritional benefits - in particular pomegranates and figs. The Bible (Deuteronomy 8:8) speaks of the seven species - wheat, barley, grapes, figs, pomegranates, olives and date honey, as well as a land 'flowing with milk and (date) honey', and these are also the basic staples of the MedDi. There are also hieroglyphic records of wine and olive exports from Canaan to Egypt. Further, in Roman times, historians recorded that the produce of the land of Israel was of particularly high quality and was served at the best tables. Such cross-cultural influences may be seen during the Passover meal, which was the basis of Jesus' Last Supper, and was itself adapted from the Greek symposium brought to the region after the conquests of Alexander the Great in the fourth century BCE. The purpose of the present review is to propose that the MedDi that originated in the Middle East may be beneficially modified by the inclusion of certain food items from biblical times.

\section{Origins of the Mediterranean diet and the biblical diet}

The MedDi based on the diet of Crete (before 1960) has been significantly correlated with extended life expectancy ${ }^{(1)}$ 
and the lowest global incidence of CHD, as well as certain cancers and other chronic diseases ${ }^{(2)}$. The MedDi is not a new diet, which is exactly the reason for its strength. In its traditional form, the food in the region was eaten according to the season and the reason. Climate dictated what was produced agriculturally, and the reason for consumption was determined by daily meal gatherings and festivals. The origins of the MedDi in fact encompass the history of Western civilisation and it has its origins in the diet and lifestyle of the Near Middle East, including those of biblical times.

The dietary laws of the Bible forbade mixing milk with meat (Exodus 23:19, 34:26 and Deuteronomy 14:21) and proscribed eating pig and sea food, allowing only animals with a cloven hoof and which 'chewed the cud' (Leviticus 11:3 and following), whereas fish had to have both fins and scales (Leviticus 11:9 and following). The reasons are not clear ${ }^{(3)}$, but might relate to eating only those animals that were preyed upon and not predators. In addition, the seven species (wheat, barley, vines, figs, pomegranates, olives and honey; Deuteronomy 8:8) in the biblical land 'flowing with milk and (date) honey' (Exodus 3:8) were given high priority ${ }^{(4)}$. Trade between Palestine and Egypt of olive oil and wine has been documented on hieroglyphs some 2000 years before Christ $^{(4)}$. Archeological excavations have uncovered the products eaten during the Minoan period dating back to the Bronze Age civilization that arose on the island of Crete (2700-1450 BCE). In the Copper Age, plants and sea food were almost the sole source of nutrients. The wall paintings Frescos at Knossos show the prime role of bread in the Cretan diet. Despite the evidence of the early origins of the MedDi, recommendations have been made to revert to the traditional MedDi as consumed in Crete 'before 1960'. But perhaps we should consider going back much further in time and take into consideration the evolution of the diet from biblical times and even before.

\section{Mediterranean lifestyle}

Human genetic profiles have not changed significantly over the past 10000 years, whereas lifestyle has been revolutionised. Modern industrialised populations are characterised by reduced energy expenditure and increased energy intake. Fat intake in the form of trans and saturated fat has increased and there is a decrease in intakes of fibre, complex carbohydrates, fruit and vegetable antioxidants, protein and calcium ${ }^{(5)}$. In the USA, there were three times more deaths due to cancer and CHD than in Crete ${ }^{(6)}$ and this differential has only increased recently. Current trends of eating while watching television promote unhealthy, quick meals and exclude social/family communication. In biblical times, meal times (generally twice a day) nurtured relationships and was an opportunity for communication. The social setting for eating promotes fixed meal times and may overcome the reluctance to change in lifestyle experienced today. The Last Supper was the traditional Passover Seder meal and was styled on the Greek symposium in which people reclined and philosophised while eating.

The Lyon Heart Study adapted the Crete diet for the French population and showed cardioprotective and anticancer effects, thereby demonstrating that the MedDi can be modified to suit other populations ${ }^{(7)}$. Other factors that may contribute to the Mediterranean lifestyle include: relaxing psychosocial environment, mild climate, preservation of the extended-family structure and even a siesta ${ }^{(8)}$, as well as regular activity, mainly through walking.

The following sections describe the health benefits of different components of the biblical diet in addition to the conventional MedDi recommended today (Table 1). Thus, discussion of the well-known nutritional qualities of grains, legumes, beans, fruit and vegetables and fish is beyond the scope of the present article.

\section{The biblical seven species}

The biblical seven species - wheat, barley, grapes, figs, pomegranates, olives and date honey, together with some indigenous foods from the Middle East - are now scientifically recognised as healthy food, and could further improve the beneficial MedDi (Fig. 1).

\section{Grains}

The origins and spread of domesticated grains have been traced to the Fertile Crescent spreading from Mesopotamia (the cradle of civilisation) ${ }^{(9-12)}$. It would appear that such food use reached the Middle East before the Greek Islands. The pivotal role of bread is further emphasised in its important status and use during festivals. In the tenth century $\mathrm{BC}$, carvings on limestone describe the harvest seasons in the land of Israel according to the Gezer calendar, which is a rhythmic enumeration of the agricultural seasons. In the dry summer months, vines were pruned and figs, dates, pomegranates and grapes ripened and the wheat was harvested, whereas in the spring season barley was harvested. Wheat flour and grain have provided the staple (breads, pitas, etc.) for different types of meals throughout the Mediterranean basin. It is the basic food par excellence and is at the centre of food culture. The health benefits of fibre and complex carbohydrates are beyond the scope of the present review.

\section{Olives}

In ancient times, olives were consumed by farmers and accompanied travellers and nomads, and in addition were a popular appetizer. Romans served olives as starters and desserts in their rich symposiums. Olive oil is a hallmark of the MedDi, and has a moderate fat content, in the range of $30-40 \%$ of energy derived from fat. The majority 
Table 1 Some beneficial effects of the components of the biblical diet

\begin{tabular}{|c|c|c|c|}
\hline Component & Health benefit & Source & Ref. \\
\hline \multirow[t]{4}{*}{ Olive oil } & Heart benefits & MUFA & 16 \\
\hline & $\begin{array}{l}\text { Antithrombotic, anti-inflammatory } \\
\text { antihypertensive effects }\end{array}$ & $\begin{array}{l}\text { Antioxidants: tocopherol, hydroxytyrosol and } \\
\text { oleuropein sterols }\end{array}$ & 53 \\
\hline & $\begin{array}{l}\text { Reduction in LDL and increase HDL } \\
\text { Anticarcinogenic }\end{array}$ & $n-9$ & \\
\hline & $\begin{array}{l}\text { High intake of olive oil is not associated with } \\
\text { weight gain }\end{array}$ & & \\
\hline \multirow[t]{2}{*}{ Red wine } & $\begin{array}{l}\text { Antiatherogenic } \\
\text { Increase longevity }\end{array}$ & Rich in polyphenols (antioxidants; e.g. resveratrol) & 54 \\
\hline & $\begin{array}{l}\text { Lower plasma fibrinogen, factor VIIc and } \\
\text { increase tissue plasminogen }\end{array}$ & & 55 \\
\hline \multirow[t]{7}{*}{ Pomegranates } & $\begin{array}{l}\text { CVD, LDL oxidation, macrophage oxidative } \\
\text { status and foam cell formation }\end{array}$ & Vitamin C & 35 \\
\hline & $\begin{array}{l}\text { Hypertension: reduces systolic blood pressure } \\
\text { through inhibition of serum angiotensin- } \\
\text { converting enzyme }\end{array}$ & Vitamin $\mathrm{B}_{5}, \mathrm{~K}$ & \\
\hline & $\begin{array}{l}\text { Viral infections: antibacterial effects against } \\
\text { dental plaque }\end{array}$ & Antioxidant polyphenols & \\
\hline & & Tannins & \\
\hline & & Free-radical tannins: & \\
\hline & & $\begin{array}{l}\text { Phytochemicals include: polyphenolic catechins, } \\
\text { gallocatechins and anthocyanins, such as } \\
\text { prodelphinidins, delphinidin, cyanidin and } \\
\text { pelargonidin }\end{array}$ & \\
\hline & & Seeds: fibre and unsaturated oils & \\
\hline \multirow[t]{2}{*}{ Barley and wheat } & Delays gastric emptying & Fibre in whole grains & 56 \\
\hline & $\begin{array}{l}\text { Diabetic benefit by slowing increase in blood } \\
\text { glucose }\end{array}$ & & 57 \\
\hline \multirow[t]{2}{*}{ Dates + figs (fruit) } & $\begin{array}{l}\text { Anti-inflammatory, anticarcinogenic, decreases } \\
\text { risk heart disease }\end{array}$ & Vitamins flavonoids & 58 \\
\hline & Antihypertensive effects & & \\
\hline \multirow[t]{2}{*}{ Nuts } & Cardio-protective effects & MUFA + PUFA (particularly walnuts) & 59 \\
\hline & & Rich in arginine & 60 \\
\hline \multirow{2}{*}{$\begin{array}{l}\text { Legumes } \\
\text { (chickpeas) }\end{array}$} & Lower LDL cholesterol & Protein, fibre, Fe, folic acid and B vitamins & 61 \\
\hline & Decreases fasting insulin & & \\
\hline \multirow{2}{*}{$\begin{array}{l}\text { Oily fish and } \\
\text { PUFA }\end{array}$} & Anti-inflammatory & $n$-3 anti-inflammatory EPA and DHA & 62 \\
\hline & Anti-Alzheimer disease properties & & \\
\hline
\end{tabular}

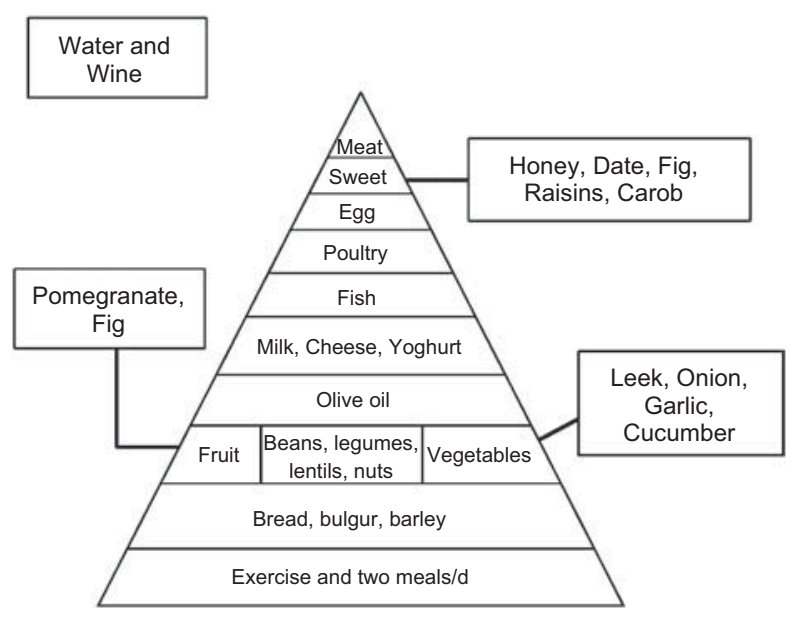

Fig. 1 Proposed additions of biblical components to the Mediterranean diet pyramid

of fat in olive oil is MUFA. Fat from edible olives and olive oil consists of oleic acid (18:1,n-9; 75\%), saturated fat (15\%) and PUFA (10\%). Olive oil is extracted from deeply pigmented olives that are rich in phytonutrients, including the phenolics hydroxytyrosol and oleorupein. When replacing saturated fat, olive oil reduces absolute levels of serum LDL, inhibits its oxidation ${ }^{(13,14)}$ and attenuates atherogenesis, with a most impressive effect shown for extra virgin oil that was enriched with green tea polyphenols ${ }^{(15)}$.

In biblical times, olive oil was cold pressed and stored in dark, opaque glass containers. This was to avoid the powerful oxidative action of sunlight. Unprocessed olive oil has the greatest antioxidant effect. Comparison of extracted phenolic compounds from extra virgin olive oil and processed olive oil showed that extra virgin olive oil had significantly greater antioxidant effects than processed olive oil ${ }^{(16)}$. It therefore seems that during the modern process of olive oil refinement, some of the phenolic content is reduced. The extra virgin unprocessed olive oil of the biblical diet has a higher concentration of antioxidants, which in turn may prevent LDL oxidation. In addition to its advantageous effects on blood cholesterol quantity, as well as quality, olive oil 
also has anti-carcinogenic action. A major component of phenols is lignans, which are found in olive oil. Owen et $a l .{ }^{(17)}$ found that they have a protective function against cancer of the breast, colorectum, oesophagus and prostate. Animal models show that the sterol squalene that is found in olive oil represses tumour growth ${ }^{(18)}$. Although the high fat content of olives could be of concern due to potential weight gain ${ }^{(19)}$, obesity is not just the result of high-fat diets ${ }^{(20)}$. Rather, MUFA have been shown to increase postprandial fat oxidation, diet-induced thermogenesis and energy expenditure ${ }^{(21)}$; hence, moderate consumption of olive oil is less likely to cause weight gain. It is of interest that in all populations studied, irrespective of geography and diet, oleic acid is the major storage adipose tissue fatty acid derived from the diet, as well as from de novo fatty acid synthesis. The reason for this is not clear, but may relate to oleic acid physico-chemical (fluidity) and biochemical (antioxidant) properties $^{(22)}$. Oleic acid is the dominant storage adipose tissue fatty acid, irrespective of where people live and what they eat ${ }^{(23)}$.

\section{Dates}

Fruit of the date palm (Phoenix Dactylifera L. Arecaceae) are an important component of the diet in the Middle East and North Africa. Dates are an ideal high-energy food as they contain high sugar content. They are also a good source of fibre and minerals, such as $\mathrm{Ca}, \mathrm{Fe}, \mathrm{Mg}, \mathrm{K}$ and $\mathrm{Zn}{ }^{(24,25)}$. Date fruit are used in folk medicine for the treatment of various infectious diseases and cancer ${ }^{(26)}$, probably as a result of their immunomodulatory activity ${ }^{(26)}$, antibacterial capacity ${ }^{(27)}$ and antifungal properties ${ }^{(28)}$. Furthermore, aqueous extracts of dates were shown to have potent antioxidant activity ${ }^{(29)}$, as they inhibit in vitro lipid and protein oxidation, and possess substantial free radical scavenging capacity. The above antioxidant activity is attributed to the wide range of phenolic compounds present in dates, including $p$-coumaric, ferulic and sinapic acids, as well as flavonoids and procyanidins ${ }^{(30,31)}$. Aviram et al. $^{(32)}$ showed for the first time the in vivo beneficial effect of Medjool or Hallawi date varieties, despite very high content of sugars, consumed by healthy subjects on serum glucose, lipids and oxidative stress. Both date varieties possessed antioxidative properties in vitro, but their antioxidant properties in vivo were unknown. In the present study, ten healthy subjects consumed for a period of 4 weeks, $100 \mathrm{~g} / \mathrm{d}$ of either Medjool or Hallawi dates. The dates did not significantly affect serum total cholesterol, or the cholesterol levels in VLDL, LDL or HDL fractions. Fasting serum glucose and TAG levels were not increased, and in fact serum TAG levels even decreased moderately but significantly by $8 \%$ and $15 \%$ after consumption of Medjool or Hallawi dates, respectively. After consumption of Hallawi dates alone, basal serum oxidative status was significantly decreased, as was the susceptibility of serum to $2,2^{\prime}$-azobis(2-amidinopropane) dihydrochloride-induced lipid peroxidation. In agreement with the above results, serum activity of the HDL-associated antioxidant enzyme paraoxonase 1 (PON1) increased significantly after Hallawi date consumption. Thus, date consumption (mainly of the Hallawi variety) by healthy subjects, in spite of their high sugar content, had beneficial effects on serum TAG and oxidative stress, and did not aggravate serum glucose and lipid profiles ${ }^{(32)}$.

\section{Pomegranates}

The pomegranate has been cultivated in the Mediterranean region since ancient times and was introduced into Egypt from Syria and from Israel around 1600 BC. In the Bible, the coat of the high priest was adorned with pomegranates (Exodus 39: 24-26). Many are the quotations concerning this luscious fruit especially in the Song of Songs: 'As a piece of pomegranate are thy temples (cheeks)' (6:7); 'I would cause thee to drink of spiced wine and the juice of my pomegranate' (8:2).

In Greek mythology, pomegranates were a symbol of life and rejuvenation. They are a potent antioxidant containing ellagitannin polyphenolic compounds such as punicalagins and punicalins, as well as ellagic acid and gallic acid. The antioxidant health benefits of pomegranate were shown to reduce LDL oxidation and it is helpful in reducing the risk of heart disease ${ }^{(33)}$. It was also shown to decrease the progression of prostate cancer ${ }^{(34)}$. Furthermore, drinking just $50 \mathrm{ml}$ of pomegranate juice (PJ) daily can significantly lower blood pressure after 3 months by $5 \%$. Leaf extracts from pomegranate may also be effective in weight loss as, without affecting plasma TAG levels, pomegranate consumption reduces fat absorption from the intestine and can be cardioprotective ${ }^{(35)}$.

Pomegranate is a major source of most potent antioxidants (tannins, anthocyanins), which are considered to also be anti-atherogenic. Studies have analysed the effect of PJ on lipoprotein oxidation, aggregation and retention and on macrophage atherogenicity in healthy subjects and atherosclerotic patients, as well as in atherosclerotic apolipoprotein E-deficient $\left(\mathrm{E}^{\circ}\right)$ mice. In vitro studies demonstrated a significant dose-dependent antioxidant capability of PJ against lipid peroxidation in plasma (by up to $33 \%$ ), in LDL (by up to $43 \%$ ) and in HDL (by up to $22 \%$ ). The water-soluble fractions of pomegranate's inner and outer peels, but not the seeds, were even stronger antioxidants against LDL oxidation than the juice itself. The antioxidative effects of PJ against lipid peroxidation in whole plasma and in isolated lipoproteins were also shown ex vivo in humans and mice. Furthermore, PJ consumption in humans increased the activity of serum paraoxonase, an HDL-associated esterase (lipo-lactonase) that acts as a potent protector against lipid peroxidation. PJ not only inhibited LDL oxidation, but also reduced two other related modifications of the lipoprotein, that is, its retention to extracellular matrix proteoglycans and its susceptibility to aggregation. The inhibitory effects of PJ consumption on macrophage ability to oxidise LDL on 
the one hand, and on the uptake of oxidised LDL on the other, contributed substantially to the attenuation of cellular cholesterol accumulation and foam cell formation, as observed in atherosclerotic mice and in atherosclerotic patients $^{(36)}$. PJ supplementation to $\mathrm{E}^{\circ}$ mice significantly reduced the number of macrophage foam cells and the size of the atherosclerotic lesion, in comparison to controls. PJ consumption by patients with carotid artery stenosis for 1 year reduced systolic blood pressure (by 18\%), oxidative stress (by 65\%) and, most importantly, the lesion size as measured by intima-media thickness (IMT; by $\sim 30 \%)^{(36)}$.

Altogether, the results of the above studies clearly demonstrate that $\mathrm{PJ}$ may be considered as a potent nutraceutical agent against $\mathrm{CVD}^{(36,37)}$.

\section{Figs}

The fig is the fruit of lust and is believed to be a symbol of fertility. The high levels of fibre in figs stimulate bowel movement. Excavations at Gezer have uncovered remains of dried figs from the Neolithic Age and an old seed was recently germinated from the Dead Sea ${ }^{(38)}$. Figs are native to the Mediterranean and grow on the ficus tree (Ficus carica), and were one of the first fruits to be cultivated. The fruit is rich in natural and simple sugars, minerals and fibre and is a good source of $\mathrm{K}, \mathrm{Ca}, \mathrm{Mg}, \mathrm{Fe}, \mathrm{Cu}$ and $\mathrm{Mn}$. Dried figs are popular as they last for a long time and have high calcium content ( $250 \mathrm{mg}$ of $\mathrm{Ca} / 100 \mathrm{~g}$ fruit weight). Potassium is also essential in regulation of blood pressure. Recently, Aviram's group observed high total polyphenol content in fig juice (with some phenolics that are unique to figs), which was associated with significant antioxidant activity against LDL oxidation ( $M$ Aviram, unpublished results).

\section{Grapes}

Vine cultivation and wine production originated in Mesopotamia. However, the culture of wine consumption belongs to the Mediterranean. An Egyptian inscription from $2375 \mathrm{BC}$ records how a military governor, Uni under the reign of Pharaoh Pepi I, sent troops to put down a revolt in Israel and how they 'destroyed the fortresses ... and felled the fig trees and vines'. A mural from the reign of Amenopsis II (fifteenth century BCE) shows the preparation of wine in Egypt by the Apirou, thought to be the Hebrews ${ }^{(39)}$. From early Egyptian civilisation through the classical period and the Roman Empire, wine has been of importance and value and exclusive to the civilised elite. Consumption of wine in the MedDi is subject to different cultural norms, especially in Muslim countries.

Red wine is rich in antioxidants from the flavonoid phenolics family, and includes cathechin, querchitin, anthocyanins and resveratrol. Resveratrol is a trihydroxystilbene phenolic compound found in the grape's seeds and skin and it has been shown to increase blood HDL cholesterol, to protect against LDL oxidation and to attenuate blood clotting. It is found in several vegetal sources and has also been shown to possess lifespan-promoting properties that mimic energy restriction in yeast and metazoans, including small mammals. While in yeast and lower metazoans resveratrol acts mainly by activating the histone deacetylase Sir2, in mammals it appears to target - in addition to the Sir2 homologue SIRT1 - several crucial pathways for the control of metabolism, including the AMPK and the insulin-IGF1 receptor axis ${ }^{(40)}$.

In the Mediterranean culture, wine is consumed in conjunction with a meal, whereas Western cultures may consume wine independent of meals and it is a more alcoholic, less acidic and a less phenolic-rich wine. Alcohol consumption on an empty stomach leads to rapid alcohol absorption and increases the risk of intoxication. It is of interest that the Rambam (Maimonides) recognised the health benefits of wine already more than 800 years ago ${ }^{(41)}$.

Red wine, but not white wine, consumption $(400 \mathrm{ml} / \mathrm{d}$, for a period of 2 weeks) by healthy volunteers, resulted in a reduced propensity of their LDL to lipid peroxidation as determined by a $46 \%, 72 \%$ and $54 \%$ decrement in the content of aldehydes, lipid peroxides and conjugated dienes, respectively. It appeared that some phenolic substances present in red wine are absorbed, bind to serum LDL and may be responsible for the antioxidant properties of red wine against LDL oxidation.

The lower antioxidant activity in white wines, in comparison to red wines, lies in the reduced content of polyphenols extracted from the grape skin, as red wine, but not white wine, is prepared following long contact time $(\sim 1$ month) of the grape skin with the produced wine. Nevertheless, it is possible to enrich white wine with the grape skin polyphenols. White wine derived from whole squeezed grapes stored for a short period of time (up to $18 \mathrm{~h}$ ) contained increased concentrations of polyphenols (from 0.35 after $3 \mathrm{~h}$, up to $0.55 \mathrm{mmol} / 1$ after $18 \mathrm{~h}$ of storage), and in parallel, exhibited increased capacity to scavenge free radicals and to inhibit copper ion-induced LDL oxidation. Addition of increasing concentrations of alcohol (up to 18\%) to the whole squeezed grapes remarkably augmented the extraction of grape skin polyphenols into the wine (up to $1.25 \mathrm{mmol} / \mathrm{l}$ ), and thus resulted in increased capacity of the wine to scavenge free radicals and to inhibit LDL oxidation to an extent similar to that of red wine. LDL oxidation inhibition was directly related to the wine's polyphenolic content $(r=0 \cdot 986)$. Thus, processing white wine with a short period of grape skins' contact in the presence of increased alcohol concentration led to extraction of their polyphenols and produced polyphenol-rich white wine with antioxidant characteristics similar to those of red wine ${ }^{(42)}$.

The potent antioxidant activity first shown for the Israeli red wine consumption was also demonstrated later on in a UK study, although the antioxidant capability of this wine was lower than that of the Israeli wine. Analyses of both red wines revealed five-fold increased levels of the polyphenolic subfraction flavonols in the studied Israeli 
red wine. Flavonols are potent polyphenolic antioxidants, and this may explain the above results. There is wide variation in the flavonol content of different red wines throughout the world and a major determinant for the production of grape flavonols is the amount of sunlight to which the grapes are exposed during cultivation, when flavonols are synthesised. Thus, the climatic conditions under which grapes are grown could explain the five-fold increased content of flavonols in the specific studied Israeli red wine compared to the studied UK wine, and hence the high antioxidant potency observed in the Israeli red wine ${ }^{(43)}$.

The effect of consuming red wine, or its major flavonoid constituents, the flavonol catechin or the flavonol quercetin, on the development of atherosclerotic lesions was studied, in relation to LDL oxidation and aggregation, using the atherosclerotic, apolipoprotein E-deficient $\left(\mathrm{E}^{\circ}\right)$ mice model $^{(44)}$. The atherosclerotic lesion area was significantly decreased in the treated mice. These results were associated with reduced susceptibility to oxidation (induced by copper ions, free radical generators or by macrophages) of LDL, isolated after consumption of red wine, quercetin and, to a lesser extent, catechin, in comparison with LDL isolated from control mice. Furthermore, PON1 activity was preserved in red wine-treated mice in comparison to PON1 inactivation in the placebo-treated mice.

LDL oxidation was previously shown to lead to its aggregation. The susceptibility of LDL to aggregation was decreased, in comparison with control mice, by $63 \%$, $48 \%$ or $50 \%$ on consuming catechin, quercetin or whole red wine, respectively. In vitro studies revealed that the inhibition of LDL aggregation by the above polyphenols could be related, at least in part, to a direct effect of the polyphenols on the LDL particle ${ }^{(45,46)}$.

\section{Additional biblical foods}

The MedDi, particularly that from Crete, has a balanced intake of polyunsaturated essential fatty acids (EFA) in a ratio of 2:1 (n-6:n-3) in contrast to the much higher ratios observed in the Western and Northern European diets, and in the $\mathrm{USA}^{(5,47)}$. In the traditional MedDi, a sweet tooth was satisfied by intake of carob, and figs stuffed with walnuts as a snack.

\section{Carob}

During the Roman persecutions, Rabbi Shimon Bar Yochai and his son survived for 13 years in a cave and survived on carob, dates and water. (Kohelet Raba $10: 8)^{(39)}$ Carob is a legume native to the Mediterranean. The word 'carob' is derived from the Arab kharrub and means 'pod', and it also gave the name carat to the measure of gold. Carob beans can be dried, ground and roasted to produce carob flour or powder. Carob is caffeinefree and naturally sweet and a rich source of calcium and potassium and smaller amounts of iron and some B vitamins. Carob binds to the intestinal tract and acts as a remedy for diarrhoea.

Aviram's research group recently measured the total polyphenol concentration in carob pod honey and found that it was comparable to concentrated PJ. The carob pod honey contained $25 \cdot 8$ (sD $2 \cdot 4) \mathrm{mg}$, whereas concentrated PJ contained only 28.3 (SD $2 \cdot 4$ ) $\mathrm{mg}$ of gallic acid equivalents $/ \mathrm{ml}$. The carob pod honey also exhibited significant dose-dependent free radical scavenging capacity. These studies demonstrated that carob pod honey contains high concentrations of total polyphenols, even in comparison to polyphenol-rich PJ.

\section{Nuts}

Nut consumption has an inverse relationship with risk for CVD. Nuts are rich in protein, fibre, phytonutrients and polyphenolic antioxidants, as well as MUFA and PUFA.

The US Food and Drug Administration have promoted the intakes of almonds, hazelnuts, peanuts, pecans, pistachios and walnuts as they contain $<8 \mathrm{~g}$ of saturated fat per $100 \mathrm{~g}$. Walnuts have a particularly high content of $n-3$ fatty acids, in addition to being high in fibre, vitamin B, magnesium and several types of antioxidants. Walnuts are active in improvement of blood vessel elasticity and in reducing atherosclerotic plaque accumulation, blood LDL cholesterol concentration and the inflammatory C-reactive protein biomarker.

Nuts are also rich sources of fibre, vitamin E and phytochemicals such as ellagic acid, flavonoids, phenolics, luteolin, isoflavones and tocotrienols. Nuts are also an excellent source of $\mathrm{Mg}, \mathrm{Zn}$, Se, Cu, riboflavin, niacin, $\mathrm{Fe}$ and folic acid. Of interest is that peanuts were shown to contain the flavonoid resveratrol ( $\sim 70 \mu \mathrm{g}$ /ounce of peanuts), whereas almonds contain the flavonoids quercetin and kaempferol.

Nut consumption reduces the risk of CHD, as shown in the Iowa Women's Health Study and that on California Seventh-Day Adventists ${ }^{(48-50)}$.

Additional antiatherogenic properties of nuts may be related to the type of the nut's proteins that are rich in the amino acid arginine and low in lysine. Arginine is a precursor of the vasodilator, antiatherogenic agent nitric oxide. Reduced arginine/lysine ratio is directly related to accelerated atherogenesis ${ }^{(51)}$.

An additional important mechanism for the protective effect of nut consumption against atherogenesis is the attenuation of oxidative stress by nut antioxidants such as vitamin E, polyphenols, flavonoids and other phytochemicals $^{(52)}$.

\section{Acknowledgements}

The authors have no conflict of interests to declare. E.M.B. conceptualized the review and wrote and edited the manuscript. M.A. provided data from his research 
and critically reviewed the many draft versions. Y.A. performed the literature review and background to the table and figure.

\section{References}

1. Trichopoulou A, Costacou T \& Bamia CDT (2003) Adherence to a Mediterranean diet and survival in a Greek population. New Engl J Med 348, 2599-2608.

2. Sofi F, Cesari F, Abbate R et al. (2008) Adherence to Mediterranean diet and health status: meta-analysis. BMJ 337, a1344.

3. Simoons FJ (1994) Eat Not This Flesh: Food Avoidances from Prebistory to the Present. Madison: University of Wisconsin Press.

4. Vamosh MF (2007) Food at the Time of the Bible. Israel: Palphot.

5. Simopoulos AP (2001) The Mediterranean diets: what is so special about the diet of Greece? The scientific evidence. Nutrition 131, Suppl. 11, 3065S-3073S.

6. Allbaugh LG (1953) Crete: A Case Study of an Underdeveloped Area. Princeton, NJ: Princeton University Press.

7. de Lorgeril M, Renaud S, Mamelle $\mathrm{N}$ et al. (1994) Mediterranean alpha-linolenic acid-rich diet in the secondary prevention of coronary heart disease. Lancet 343, 1454-1459.

8. Trichopoulou A \& Lagiou P (1997) Healthy traditional Mediterranean diet: an expression of culture, history and lifestyle. Nutr Rev 55, 383-389.

9. Braun $\mathrm{T}$ (1991) Ancient Mediterranean food. In The Mediterranean Diets in Health and Disease, pp. 10-58 [GA Spiller, editor]. New York: Van Nostrand Reinhold.

10. Harlan JR \& Zohary D (1966) Distribution of wild wheats and barley. Science 153, 1074-1080.

11. Zohary D \& Hopf M (1973) Domestication of pulses in the old world. Science 182, 887-894.

12. Redman CL (1978) The Rise of Civilization: From Early Farmers to Urban Society in the Ancient Near East. San Fransico, CA: WH Freeman \& Co.

13. Aviram M \& Eias K (1993) Dietary olive oil reduces lowdensity lipoprotein uptake by macrophages and decreases the susceptibility of the lipoprotein to undergo lipid peroxidation. Ann Nutr Metab 37, 75-84.

14. Berry EM, Eisenberg S, Friedlander Y et al. (1995) Effects of diet rich in monounsaturated fatty acids on plasma lipoproteins - The Jerusalem Nutrition Study. III. Monounsaturated vs saturated fatty acids. Nutr Metab Cardiovasc Dis 5, 55-62.

15. Rosenblat M, Volkova N, Coleman R et al. (2008) Antiatherogenicity of extra virgin olive oil and its enrichment with green tea polyphenols in the atherosclerotic apolipoprotein E-deficient mice: enhanced macrophage cholesterol efflux. J Nutr Biochem 19, 514-523.

16. Fitó M, Covas MI, Lamuela-Raventós RM et al. (2000) Protective effect of olive oil and its phenolic compounds against low density lipoprotein oxidation. Lipids 35, 633-638.

17. Owen RW, Giacosa A, Hull WE et al. (2000) The antioxidant/anticancer potential of phenolic compounds isolated from olive oil. Eur J Cancer 36, 1235-1247.

18. Newmark HL (1999) Squalene, olive oil, and cancer risk. Review and hypothesis. Ann New York Academy Sci $\mathbf{8 8 9}$, 193-203.

19. Ferro Luzzi A, James WP \& Kafatos A (2002) The high fat Greek diet: a recipe for all? Eur J Clin Nutr 56, 796-809.

20. Willett WC \& Leibel RL (2002) Dietary fat is not a major determinant of body fat. Am J Med 113, Suppl. 9B, S47-S59.

21. Soares MJ, Cummings SJ, Mamo JC et al. (2004) The acute effects of olive oil vs. cream on postprandial thermogenesis and substrate oxidation in postmenopausal women. $\mathrm{Br} J$ Nutr 91, 245-252.

22. Berry EM (1997) The biological properties of oleic acid. In Handbook of Essential Fatty Acid Biology; Biochemistry, Physiology and Behavioral Neurobiology, pp. 89-101 [DI Mostofsky and S Yehuda, editors]. Totowa, NJ: Humana Press Inc.

23. Berry EM (1996) Oleic acid, adipose tissue composition and the Mediterranean diet. Cell Pharmacol 3, 373-377.

24. Al-Shahib W \& Marshall RJ (2003) The fruit of the date palm: it's possible use as the best food for the future? Int $J$ Food Sci Nutr 54, 247-259.

25. Ali A, Al-Kindi YS \& Al-Said F (2008) Chemical composition and glycemic index of three varieties of Omani dates. Int $J$ Food Sci Nutr 22, 1-12.

26. Puri A, Sahai R, Singh KL et al. (2000) Immunostimulant activity of dry fruits and plant materials used in Indian traditional medical system for mothers after child birth and invalids. J Ethnopharmacol 71, 89-92.

27. Sallal A-K \& Ashkenani A (1989) Effect of date extract on growth and spore germination of Bacillus subtilis. Microbios 59, 203-210.

28. Shraideh ZA, Abu-El-Teen KH \& Sallal A-K (1998) Ultrastructural effects of date extract on Candida albicans. Mycopathologia 142, 119-123.

29. Vayalil PK (2002) Antioxidant and antimutagenic properties of aqueous extract of date fruit (Phoenix dactylifera L. Arecaceae). J Agric Food Chem 50, 610-617.

30. Hung YJ, Tomas-Barberan FA, Kader AA et al. (2006) The flavonoid glycosides and procyanidin composition of Deglet Noor dates (Phoenix dactylifera). J Agric Food Chem 54, 2405-2411.

31. Al-Farsi M, Alasalvar C, Morris A et al. (2005) Comparison of antioxidant activity, anthocyanins, carotenoids, and phenolics of three native fresh and sun-dried date (Phoenix dactylifera L.) varieties grown in Oman. J Agric Food Chem 53, 7592-7599.

32. Rock W, Rosenblat M, Borochov-Neori H et al. (2009) Effects of date (Phoenix dactylifera L., Medjool or Hallawi variety) consumption by healthy subjects on serum glucose and lipid levels and on serum oxidative status: a pilot study. J Agric Food Chem 57, 8010-8017.

33. Aviram M, Rosenblat M \& Fuhrman B (2008) Pomegranate phenolic antioxidant activities protect against cardiovascular diseases. In Phytochemicals: Aging and Health, pp. 133-152 [MK Meskin, WR Bidlack, K Randolph, editors]. New York, NY: Taylor \& Francis Group, LLC.

34. Pantuck A, Leppert J, Zomorodian N et al. (2006) Phase II study of pomegranate juice for men with rising prostatespecific antigen following surgery or radiation for prostate cancer. Clin Cancer Res 12, 4018-4026.

35. Aviram M, Volkova N, Coleman R et al. (2008) Pomegranate phenolics from the Peels, Arils, and Flowers are antiatherogenic: studies in vivo in the atherosclerotic apolipoprotein $\mathrm{E}$, deficient $\left(\mathrm{E}^{\circ}\right)$ mice and in vitro in cultured macrophages and lipoprotein. J Agric Food Chem 56, 1148-1157.

36. Aviram M, Rosenbalt M, Gaitini D et al. (2004) Pomegranate juice consumption for 3 years by patients with carotid artery stenosis reduces common carotid intima-media thickness, blood pressure and LDL oxidation. Clin Nutr 23, 423-433.

37. Aviram M, Dornfeld L, Rosenblat M et al. (2000) Pomegranate juice consumption reduces oxidative stress, atherogenic modifications to LDL, and platelet aggregation: studies in humans and in atherosclerotic apolipoprotein E-deficient mice. Am J Clin Nutr 71, 1062-1076.

38. Sallon S, Solowey S, Cohen Y et al. (2008) Germination, genetics, and growth of an ancient date seed. Science 320, 1464.

39. Goor A \& Nurock M (1968) The Fruits of the Holy Land. Jerusalem: Israel University Press. 
40. Fröjdö S, Durand C \& Pirola L (2008) Metabolic effects of resveratrol in mammals - a link between improved insulin action and aging. Current Aging Sci 1, 145-151.

41. Maimonides M (1963) Treatise on Asthma [S Muntner, editor]. Philadelphia, PA: J B Lippincott Company.

42. Fuhrman B, Volkova N, Soraski A et al. (2001) White wine with red wine-like properties: increased extraction of grape skin polyphenols improves the antioxidant capacity of the derived white wine. J Agric Food Chem 49, 3164-3168.

43. Howard A, Chopra M, Thurnham D et al. (2002) Red wine consumption and inhibition of LDL oxidation: what are the important components? Med Hypotheses 59, 101-104.

44. Hayek T, Fuhrman B, Vaya J et al. (1997) Reduced progression of atherosclerosis in the apolipoprotein E-deficient mice following consumption of red wine, or its polyphenols quercetin, or catechin, is associated with reduced susceptibility of LDL to oxidation and aggregation. Arterioscler Thromb Vasc Biol 17, 2744-2752.

45. Fuhrman B, Lavy A \& Aviram M (1995) Consumption of red wine with meals reduces the susceptibility of human plasma and low-density lipoprotein to lipid peroxidation. Am J Clin Nutr 61, 549-554.

46. Fuhrman B \& Aviram M (1996) White wine reduces the susceptibility of low density lipoprotein to oxidation. Am J Clin Nutr 63, 403-404.

47. Dubnov G \& Berry EM (2003) n-3:n-6 ratio: the Israeli paradox. World Rev Nutr Diet 92, 81-91.

48. Sabate J (1999) Nut consumption, vegetarian diets, ischemic heart disease risk, and all-cause mortality: evidence from epidemiologic studies. Am J Clin Nutr 70, Suppl. 3, 500S-503S.

49. Prineas RJ, Kushi LH, Folsom AR et al. (1993) Walnuts and serum lipids. New Engl J Med 329, 359-360.

50. Fraser GE, Sabate J, Beeson WL et al. (1992) A possible protective effect of nut consumption on risk of coronary heart disease. Arch Int Med 152, 1416-1424.

51. Kritchevsky D, Tepper SA, Czarnecki SK et al. (1982) Atherogenicity of animal and vegetable protein - influence of the lysine to arginine ratio. Atherosclerosis 41, 429-431.
52. Bolling BW, McKay DL \& Blumberg JB (2010) The phytochemical composition and antioxidant actions of tree nuts. Asia Pac J Clin Nutr 19, 117-123.

53. Bes-Rastrollo M, Sanchez-Villegas A \& De la Fuente C (2006) Olive oil consumption and weight change: the SUN prospective cohort study. Lipids 41, 249-256.

54. Carluccio M, Siculella L \& Ancora M (2003) Olive oil and red wine antioxidant polyphenols inhibit endothelial activation: antiatherogenic properties of Mediterranean diet phytochemicals. Arterioscler Thromb Vasc Biol 23, 622-629.

55. Mezzano D, Leighton F \& Martínez C (2001) Complementary effects of Mediterranean diet and moderate red wine intake on haemostatic cardiovascular risk factors. Eur J Clin Nutr 55, 444-451.

56. Giacco R, Parillo M \& Rivellese A (2000) Long-term dietary treatment with increased amounts of fiber-rich lowglycemic index natural foods improves blood glucose control and reduces the number of hypoglycemic events in type 1 diabetic patients. Diabetes Care 23, 1461-1466.

57. Chandalia M, Garg A, Lutjohann D et al. (2000) Beneficial effects of high dietary fiber intake in patients with type 2 diabetes mellitus. New Engl J Med 342, 1392-1397.

58. Maron D (2004) Flavonoids for reduction of atherosclerotic risk. Curr Atheroscl Rep 6, 73-78.

59. Mattes RD, Kris-Etherton PM \& Foster GD (2008) Impact of peanuts and tree nuts on body weight and healthy weight loss in adults. J Nutr 138, 1741S-1745S.

60. Zambón D, Sabaté J \& Muñoz S (2000) Substituting walnuts for monounsaturated fat improves the serum lipid profile of hypercholesterolemic men and women. A Randomized Crossover Trial. Ann Int Med 132, 538-546.

61. Pittaway J, Robertson I \& Ball M (2008) Chickpeas may influence fatty acid and fiber intake in an ad libitum diet, leading to small improvements in serum lipid profile and glycemic control. J Am Diet Assoc 108, 1009-1013.

62. Morris MC, Evans DA, Bienias JL et al. (2003) Consumption of fish and $\mathrm{n}-3$ fatty acids and risk of incident Alzheimer disease. Arch Neurol 60, 940-946. 